OPEN ACCESS

International Journal of Management \& Entrepreneurship Research

P-ISSN: 2664-3588, E-ISSN:2664-3596

Volume 2, Issue 5, P.No. 380-390, October, 2020

Fair East Publishers

Journal Homepage: www.fepbl.com/index.php/ijmer

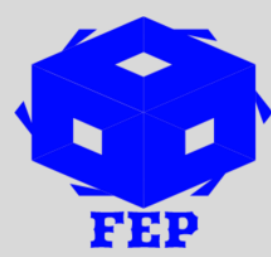

\title{
DEVELOPMENT COMMUNICATION AND PERFORMANCE IN THE PROJECTS OF LOW-INCOME COUNTRIES: THE CASE OF THE REGIONAL SUPPORT PROJECT FOR PASTORALISM IN THE SAHEL (PRAPS) IN NIGER
}

\author{
Régina Soutongo Bande ${ }^{1}$, Dr. Théophile Bindeouè Nassè ${ }^{2,3}$ \\ ${ }^{1}$ Regional Support Project for Pastoralism in the Sahel (PRAPS), Ouagadougou (Burkina Faso). \\ ${ }^{2}$ University for Development Studies, Wa (Ghana) \\ ${ }^{3}$ Saint Thomas D’Aquin University, Ouagadougou (Burkina Faso)
}

\begin{abstract}
*Corresponding Author: Dr. Théophile Bindeouè Nassè
Corresponding Author Email: nassetheophile2009@ gmail.com
\end{abstract}

Article Received: 25-09-20 Accepted: 10-10-20

Published: $15-10-20$

Licensing Details: Author retains the right of this article. The article is distributed under the terms of the Creative Commons Attribution-Non Commercial 4.0 License (http://www.creativecommons.org/licences/by-nc/4.0/) which permits non-commercial use, reproduction and distribution of the work without further permission provided the original work is attributed as specified on the Journal open access page.

\section{ABSTRACT}

In West Africa, pastoral systems provide more than $80 \%$ of income to rural households and are a vital food source for urban populations. The six Sahelian countries (Burkina Faso, Chad, Mali, Mauritania, Niger, and Senegal) have around 20 million pastoralists who raise a population of 60 million cattle and 160 million small ruminants. However, projects in pastoral systems sometimes experience communication-related failures. Development communication is very important within the Regional Support Project for Pastoralism in the Sahel (PRAPS). Still, it must be recognized that some of the objectives are not achieved because of certain factors related to communication which are not taken into account. This state of affairs raises a question: How can the objectives set by PRAPS be achieved with an efficient communication? The approach used here is inductive, and the research is conducted through qualitative interviews carried out with focus groups. Data is collected using a digital recorder, then, the data is hand-transcribed and analyzed. The results show not only that development communication has effects on project results, but also that development communication has effects on the performance of projects of the Regional Support Project for Pastoralism in the Sahel (PRAPS). It is recommended that project supervisors should put an emphasis on an effective development communication in order to achieve the objectives of the Regional Support Project for Pastoralism in the Sahel (PRAPS). 
Keywords: Communication, Development, Results, Pastoralism, Developing Countries, Performance, Sahel.

\section{INTRODUCTION}

Pastoralism contributes to the integration of sub-regional markets in Africa. Its economic importance for the Sahelian countries is indisputable, while also contributing greatly to the resilience of ecosystems and populations. However, several misconceptions, and negative prejudices are attached to pastoralism due to ignorance and a misunderstanding of the context (Nassè, 2012; Bande \& Nassè, 2017). Also, very few resources are allocated to pastoralism due to stereotypes alone: few countries allocate $10 \%$ of their budgets to this sector. Indeed, the policies, programs and development projects initiated over several decades in the Sahel have given pride of place to the sole agriculture sector. In a context of poor understanding of pastoralism, the altered appreciations of the lifestyles of pastoral communities have contributed to the development of stereotypes, on pastoralists and their households as well as the core activities that they develop. The so-called development and improvement of conditions for pastoralists advocated over the years in an all-encompassing context have remained weak or even absent. This 'top-down' approach to development was quickly doomed to failure because it was not inclusive at all. How to explain such a state of affairs, if we consider that the mechanisms implemented in these dynamics are developed by experts in the field for such a lack of results and positive impacts on the well-being of the beneficiaries?

The observation is that beyond the strategies, the development projects drawn up and implemented in a number of African countries have obscured the integration of communication as an essential factor in the search for performance. This option of governments and development partners turned out to be a great failure due to the noninvolvement of those first concerned, often perceived as receptacles to be filled with the planned activities. This diagram, corresponding to an information process, could only result in failure of insufficient impact. The research is focused on the case of PRAPS-Niger, whose development objective of PRAPS hereinafter aim to improve access to essential means and production services and to markets for pastoralists and agro-pastoralists in selected crossborder areas; and along the transhumance axes in the six countries of the Sahel, and to improve the capacity of these countries to respond in time and effectively in the event of pastoral crises or emergencies. It is a question of showing how communication can influence the achievement of the objectives of the PRAPS Niger. The general objective is to show the importance of communication for development in the achievement of objectives for the projects in developing countries. The specific objectives of this paper are: first, to examine the effects of development communication on the results of PRAPS projects; second, to assess the place of development communication on the performance of PRAPS; third, to identify and formulate recommendations for the proper implementation of development communication in the PRAPS.

\section{LITERATURE REVIEW}

\section{* Underpinning Theories}

$\square$ Theory of participatory management: Guyot (2011), Jones and Filos (2015), Bernardes (2015), and Nassè (2016) demonstrate that to achieve some sustainable results, the various 
actors must express themselves, and propose and participate throughout the project or company cycle. This approach highlights the participation of all actors.

$\square$ The theory of participatory communication: Authors such as Uphoff (1984), Bessette (2004), Kaboré (2016) show that the success of a business, a project or a successful business depends on the way it communicates. The participation of the various actors who intervene in the life of the company is very capital for a communication which wants to be effective and whose aim is to promote a sustainable development.

$\square$ Cultural theory relating to the behavior of individuals: Authors such as Nassè (2019), Diop (2012), Nassè et al. (2016) demonstrate that culture is an important dimension to consider in social life or in community space. These authors clearly show that culture does have a very strong influence on the behavior of individuals.

\section{* Conceptual Framework}

Development communication: For Bessette (2004) development communication is the one that engages people in a given community to bring their own participation to reach the goals of sustainable development; thus, not only it is participatory, but also it is an individual contribution to a collective ideal. Mc Call (2010), communication for development is a strategy that promotes the social well-being of a given community. The author defines it in these terms "More than a simple strategy, communication for development is a social process based on the promotion of dialogue between the community and decision-makers at local, national and regional level. Its aim is to promote, develop and implement policies and programs that improve the quality of life".

In the present research development communication also known as communication for development refers to an efficient participatory communication that helps people to achieve better results that could influence sustainable development, benefitable for the present generations but also for future generations.

$\square$ Result: Gómez, Olivera, and Velasco, (2009) view the concept of result as some outcomes generated by a certain performance at an organisation level. In this research the concept of results can be understood as the outcomes of a project. These outcomes may or may not be achieved.

Performance: Nassè (2015) the concept of performance corresponds to notions such as profit and growth in terms of turnover. Kumar, Nirmala, and Mekoth (2015) define performance to be a growth or profitability again a market share. For Ampofo, Nassè, and Akouwerabou (2020), the concept of performance is nothing but the ability to bring out some better results. Here, the concept of performance is understood to be the aptitude of bring out some excellent results that are benefitable to the organization.

\section{Research Assumptions}

$\mathbf{P}_{1}$ : Development communication has positive effects on the results of projects.

$\mathbf{P}_{2}$ : Development communication has positive effects on the performance of projects.

\section{Research Model}

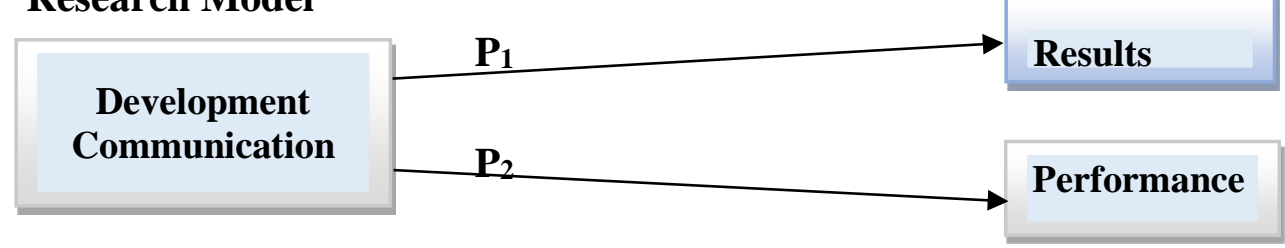

Figure 1: Research model (Fieldwork, 2017) 


\section{METHODOLOGY}

Research Design: The epistemological posture is constructivist based on a qualitative approach. This qualitative study is based on a documentary analysis, semi-structured interviews, focus groups with experts, participant observations. During the research process, it was a question of simultaneously using several methods of data collection in the intervention area of PRAPS- Niger. This option is justified by the search for "triangulation" which will make it possible to bring together the data collected for their cross-referencing and their complementarity. An in-depth documentary analysis was carried out and the research generally concerned the documentation relating to the Regional Support Project for Pastoralism in the Sahel (PRAPS) both at the regional level and in the PRAPS Countries. Specifically, special attention will be devoted to PRAPS Niger, and the area covered by the research.

Research Areas and Context: The context of the research is Niger and PRAPS-Niger covers different regions such as Agadez, Diffa, Maradi, Tahoua, Tillabéri and Zinder. However, this research is restricted three main area that are Diffa, Maradi and Tillabéri.

Study Population: The respondents are all participants of the PRAPS-Niger and the beneficiaries. The total number of participants is 720 with 547 men and 173 women as shown by Figure 2 in the appendices. Concerning the participants' level, out of the 720 participants, 517 respondents are illiterate, 72 participants have a primary school level, 58 participants have a high school level, 65 participants have a University level and 8 participants are $\mathrm{Ph} \mathrm{D}$ holders (see Table 2 in the appendices).

Data Collection and Analysis: The data is collected using the delphi method. From the 720 respondents that are gathered for the group discussion, a purposeful sample of experts and key actors is drawn, to be interviewed. The number of the key respondents is 10 (six men and four women). Once the data collected, it is transcribed by hand and the verbatim content is then analyzed. The analysis is completed by a documentary review on the relevant information to be collected in Niger from technical services, technical and financial partners (the World Bank and MCC-Niger), umbrella organizations operating in the field of pastoralism (RBM, APESS, AREN, etc.) and beneficiaries of the intervention area. It allowed us to collect information to understand the concepts according to the currents thought and to analyze them critically of the different related to our study. An analysis also consisted of consulting articles and documents that are in line with the research topic.

Ethical considerations: The identity of the respondents is kept anonymous (Nassè, 2020).

\section{RESULTS}

The qualitative data collected in the previous phase were the subject of an analysis and the verbatim is transcribed by hand, then analyzed in order to provide answers to the postulates identified with regard to this research. The results of the present research also allow the researchers to perceive some efforts in participatory communication.

\section{- Development Communication and Results}

From the analysis of the results shows that the experience of associating organization's pastoralists and farmers in activities relating to improving health through communication initiatives for development contributes progressively to the improvement of the results. The interviewed beneficiaries within the framework of the research attest that their 
involvement and participation is effective in the implementation of project activities through the communication developed. Indeed, development communication positively influences the results within the framework of the PRAPS-Niger project; as evidenced by the verbatim records collected. As one can notice the communication is done through different channels towards the different actors of the project. For instance, one key actor in the market chain noted:

Our members are aware of information on their trading activities and on other largescale markets through the channel of various media adapted to disparate levels of education: weekly news bulletins in several local languages broadcast on the National Radio and its regional branches, the bulletin board, and the LABAROUN information broadcast platform provides the prices of products from the Livestock Market Information System (SIM) for a subscription fee. We make members aware of the availability of information in order to avoid wasting. (Respondent 10, chief)

This communication has produce some positive results. Thus, development communication has some positive effects on the results expected.

"The sensitization that we had to do through the radio made it possible to be able to vaccinate the herd which made it possible to improve the health of the animals, and the results are impressive" Respondent 1 (expert in communication, Man, 27 years old ).

The PRAPS is an innovative project that addresses the issues of the PRAPS in its entirety: animal health, natural resource management, access to markets and management of pastoral crises. All the aspirations of AREN are reflected in the Project. PRAPS is a source of pride, a collective commitment. Its particularity is its extension to the entire Nigerien territory. Respondent, 3(Man).

30 teams composed of 10 persons each are taking part to the work in the valley. The women represent four teams. I appreciate the project that helps to protect the environment and recover fertile lands in my village; what allows me to get some income for my family, the school fees for the children and even other needs of the family. Respondent 7 (Woman, leader, 56 years old)

Consequently, one can conclude that the first proposition is confirmed.

P1: Development communication has some positive effects on the results of projects.

Development Communication and Performance

The present results shows that the development communication has also increase the performance of the project. As an effect, development communication has some positive effects on the achievement of project objectives. Thus, the optimal management of resources cannot be dissociated from development communication. Here are the views of some respondents: 
"The objectives of PRAPS seem to be achieved but we must always work to better achieve them' Respondent 5(Man, Head of project, 35 years old).

With the support of our association, as a breeder and pastor, I also understood the importance of vaccination in a context marked by mobility. I also understood that refusing to vaccinate my herd is exposing it to new zoonoses like Ebola, rift valley fever etc. With my fellow breeders, the social mobilization campaign also allowed us to understand that having your cattle vaccinated is a guarantee of income for our households, by making vaccination a priority; we too can convince the breeders of the region from Maradi Region and other regions that to vaccinate your animals is to opt for their protection, to have healthy animals for the market and consequently to increase their income. Respondent 8 (Man, leader)

Indeed, thanks to appropriate communication, the project has been able to vaccinate the herd and this activity has positive effects in term of performance, what draw other actor to also be engaged to invite their peers to vaccinate their herd. The conclusion is that the second proposition is confirmed. Consequently the second proposition is confirmed

$\mathbf{P}_{2}$ : Development communication has some positive effects on the performance of the projects.

\section{DISCUSSION}

\section{- Development Communication and Results}

The review of the literature shows that communication can help to the achievement of some significant goals. Giri and Kumar (2010) have shown that organizational communication has some effects on employee's job satisfaction. Conversely, this research rather put an emphasis on the fact that development communication has some positive effects on the results of the project. The development communication has some effect on the outcomes of the project.

- Development Communication and Performance

Some previous authors such as Kibe (2014) show that communication strategies have some effects on performance; and Hee et al. (2009) underline the impact of communication on employee's performance. Nevertheless, it emerges from this research that development communication has some positive or effects on the achievement of the overall objectives of PRAPS-Niger. The results are satisfactory for the different actors who recognize the achievements of the objectives.

The present research show that development communication has some positive effects on the performance of the project.

\section{CONCLUSION AND RECOMMENDATIONS}

The present research has some conceptual contributions, managerial contributions and some methodological contributions.

Conceptual Contributions: The present research has made it possible to enrich some concepts, in particular the concept of development communication even if this one had already been defined in the previous literature. 
Managerial Contributions: this research shows that communication has a preponderant and very important place for projects in very low-income countries and for this, it must involve development communication in project-related activities.

Methodological Contributions: The methodology adopted for the data collection is linked to the specific context of Niger; and this does not allow the results to be generalized.

Taking into account the concept of development communication in the management of pastoral projects could be the response to the success of these projects, the response to the achievement of the ideal of sustainable development and to the fight against poverty, through jobs creation. The formulation and implementation of the PRAPS projects constitutes a case study in terms of communication for the information, mobilization, involvement and support of beneficiaries for the expected results. Although, the project is at the end of its second, achievements have been recorded with the support of the Farmers' Organizations which are credible and sure levers to instill changes in behavior among their peers, pastoralists and agropastoralists. These achievements obtained in animal health through vaccination campaigns, cross-border dialogue between the Maradi Region and Katsina State for transhumance soothed, land regeneration by dunes' fixation; the involvement of market chain actors in improving their income and better management of pastoral crises in the Diffa region contribute to the achievement of the Project Development Objective (PDO). The lessons learned will be able to better orient communication actions for development, which intends to make the beneficiary, ignoring or refusing new behaviors, better understand, accept and above all integrate them into his daily life. PRAPS works to improve the productivity, sustainability and resilience of pastoral livelihoods, in accordance with the spirit of the Nouakchott Declaration on pastoralism. Its interventions in particular create jobs for young people and women, increase the added value of pastoral products, guarantee sustainable management of natural resources and ultimately improve the living conditions of the 400,000 pastoral households in Niger and their livestock. Pastoral populations are aware of their role in the PRAPS and they participate for some better results to their advantages.

- Recommendations for the pastoral project's authorities: It is necessary to focus on development communication if we really want to have some better results and some benefits in achieving the objectives of PRAPS-Niger.

- Future Research: It would be useful not only to extend this research in other projects or to conduct it in other African countries to see if the results will be the same.

\section{References}

Ampofo, J. A., Nassè, T. B., \& Akouwerabou, L. (2020). The effects of stress on performance of workers in Ghana health service in Wa municipal. International Journal of Management \& Entrepreneurship Research, 2(4), 212-230.

Bande, R. \& Nassè T. B. (2017). Place of communication for development in the projects of developing countries: the case of the Regional Pastoralism Support Project (PRAPS). Dakar, DA: ISRA, CIRAD.

Bernardes, A. (2015). Implementation of a participatory management model: analysis from a political perspective. Journal of Nursing Management, 23(7), 888-897.

Bernard, F. (2006). Organiser la communication d'action et d'utilité sociétales. Le paradigme de la communication engageante. Communication \& Organisation, 29, 65-84. 
Bessette, G. (2004). Communication et participation communautaire: Guide pratique de communication participative pour le développement. Les Presses de l'Université Laval.

Bessette, G. (2007). Eau, terre et vie. Communication participative pour le développement et gestion des ressources naturelles. Les Presses de l'Université Laval/l'Harmattan/Centre de Recherche pour le Développement International (CRDI).

Diop, F. (2012). L'influence de la religion musulmane sur le comportement de consommation au Sénégal. Dakar, DA : École Supérieure Polytechnique de Dakar, Université Cheikh Anta Diop, Sénégal.

Décalaration de Nouakchott sur le pastoralisme, (2013). Nouakchott, NO: http://portails.cilss.bf/IMG/pdf/DECLARATION_VERSION_FINALE_FRENCH_ad optee_29_octobre_2013.pdf

Document d'évaluation de Projet Régional d'Appui au Pastoralisme au Sahel (PRAPS) (2015).

Fondation Joseph Ki-Zerbo, (2010). Education et développment en Afrique: 50 ans de reflexion et d'actions.Ouagadougou, OU: Fondation Joseph Ki-Zerbo.

Giri, V. N., \& Kumar, B. P. (2010). Assessing the impact of organizational communication on job satisfaction and job performance. Journal of Psychological Studies, 55(2), 137142.

Gómez, R. R., Olivera, M. G., M, \& Velasco, M. A. R. (2009). Implementing a subnational results oriented management and budgeting system. Bogota, BO: Centro de Investigación Económica y Social.

Guyot, S. (2011). The instrumentalization of participatory management in protected areas: the ethnicization of participation in the kolla-atacameña region of the Central Andes of Argentina and Chile. Journal of Latin American Geography, 10(2), 9-36.

Hee, C. O., Qin, D. A. H., Kowang, T. O., Husin, M. M., \& Ping, L. L. (2019). Exploring the impact of communication on employee performance. International Journal of Recent Technology and Engineering, 8(3S2), 654-658.

Jones, N., \& Filos, E. (2015). Exploring perceptions on participatory management of NATURA 2000 forest sites in Greece. Forest Policy and Economics, 56, 18. doi:10.1016/j.forpol.2015.03.010.

Kibe, C. W. (2014). Effects of communication strategies on organizational performance: A case study of Kenya ports authority. Journal of Business and Management, 6(11), 611.

Kumar, P., Nirmala, R., \& Mekoth, N. (2015). Relationship between Performance Management and Organizational Performance Acme Intellects International Journal of Research in Management, Social Sciences \& Technology. 9(9), 1-13.

Mc Call, E. (2010). La communication pour le développement: accroître l'efficacité des nations unies. New York, NY: United Nations Development Program.

Ministère de L'élevage et des Ressources Animales,(2009-2016). Loi d'orientation du Burkina Faso relative au pastoralisme, décret du 13 décembre 2002. Plan national de développement de l'elevage. 
Nassè, T. B. (2020). Religious beliefs, consumption and inter-religious differences and similarities: is syncretism in consumption a new religious dynamics? International Journal of Management \& Entrepreneurship Research, 2(2), 59-73.

Nassè, B. T. (2018). Pratiques religieuses et comportement de consommation dans un contexte africain: une étude exploratoire sur les consommateurs au Burkina Faso. Thèse de Doctorat en sciences de Gestion, spécialité marketing. Ouagadougou, OU: Université Aube nouvelle en collaboration avec l'Université Cheikh Anta Diop.

Nassè, B. T. (2016). L'équité interne dans la gestion de la relation client: une étude comparative quantitative de trois entreprises privées du Burkina Faso. Journal OuestAfricain des Sciences de Gestion, 1(1), 38 -54.

Nassè, B. T. (2016) L'influence de la religiosité sur les comportements des consommateurs à l'égard des boissons industrielles non alcoolisées. Journal Ouest Africain de Sciences de Gestion, 1(2), 1-28.

Nassè, T. B. (2015). Internal equity as a factor of companies' economic profitability: A comparative study of three private companies in Burkina Faso through a qualitative approach. Saarbrucken, SA: Lamber Academic Publishing.

Nassè T. B. (2012). Succeeding in Church missionarial work in West Africa: the necessity of understanding the West African environment. Saarbrücken: Lambert Academic Publishing.

Ordonnance 2010-029 du 20 mai 2010 relative au pastoralisme, Niger, (2010).

Niger - Recensement Général de la Population et de l'Habitat (2012). Évaluation de l'impact de la communication pour le développement (2008). Ouagadougou, OU: rapport BCO.

Kaboré, P. (2016). Mémoire, Communication participative et management des projets : cas du Projet de développement de l'agriculture du Millenium Challenge Account (MCA$B F)$. Ouagadougou, OU: MCA-BF.

\section{Acknowledgements}

The research team wants to acknowledge the efforts made by the various respondents, and the support of the editorial board of the International Journal of Management \& Entrepreneurship Research. The research team is also deeply indebted to Dr. Théophile Bindeouè Nassè for his steady support and contributions to this research project.

\section{Conflict of Interest Statement}

No conflict of interest has been declared by the two authors.

\section{Appendices}

Table 1

Reconstructed Sites by PRAPS

\begin{tabular}{|c|c|c|}
\hline Region & Sites & Dimension in ha \\
\hline \multirow[b]{2}{*}{ Maradi } & Katakaou commune of Guidan Roumdji & 50 ha \\
\hline & Ajekoria & 50 ha \\
\hline Dosso & Kieché & 50 ha \\
\hline Zinder & Gouré & 50 ha \\
\hline \multirow[b]{2}{*}{ Diffa } & Maine Soroa & 250 \\
\hline & Konna Gao : & 50 ha \\
\hline
\end{tabular}

(Source: Fieldwork, 2017) 
Table 2

\begin{tabular}{|c|c|c|}
\hline Education status & Number & Frequency \\
\hline Illiterate & 517 & $71.80 \%$ \\
\hline Primary School Level & 72 & $10 \%$ \\
\hline Secondary School Level & 58 & $8.05 \%$ \\
\hline University Level & 65 (with 8 holding a Ph D). & $9.02 \%$ \\
\hline Total & 720 & $100 \%$ \\
\hline
\end{tabular}

(Source: Fieldwork, 2017)

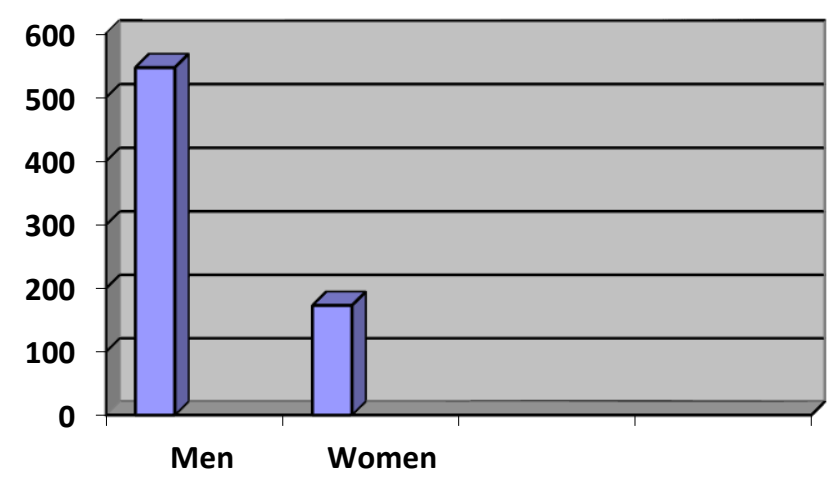

Figure 2: Number of men and women (Source: Fieldwork, 2017)



Picture 1: Herd in Niger (Source: fieldwork, 2017) 




Picture 2: Vaccination of herd by the PRAPS -Niger program (Source: fieldwork, 2017) 